Please do not remove this page

RMIT

UNIVERSITY

\title{
Libraries, librarians and librarianship in the colony of Victoria
}

Reynolds, Susan

https://researchrepository.rmit.edu.au/esploro/outputs/9921863723401341/filesAndLinks?institution=61RMIT_INST\&index=null

Reynolds, S. (2009). Libraries, librarians and librarianship in the colony of Victoria. Australian Academic \& Research Libraries, 40(1), 50-64.

https://researchrepository.rmit.edu.au/discovery/fulldisplay/alma9921863723401341/61RMIT_INST:Resea rchRepository

Repository homepage: https://researchrepository.rmit.edu.au

(C) 2009 Australian Academic and Research Libraries

Downloaded On 2023/04/27 01:08:33 +1000

Please do not remove this page 


\section{LIBRARIES, LIBRARIANS AND LIBRARIANSHIP IN THE COLONY OF VICTORIA}

\section{Sue Reynolds}

This paper examines the role of Redmond Barry in the establishment and management of the four major institutional libraries established in the Colony of Victoria after its separation from New South Wales. The libraries of the Parliament, University, Supreme Court, and the Melbourne Public Library were all instigated by Redmond Barry, a judge of the Supreme Court of Victoria. They are considered with the aim of determing if Barry saw each as requiring the same management strategy from a personal view of how libraries should be run, or if they reflected the management strategies of other libraries of the same type established in the same time period.

AARL March 2009 vol 40 no 1 pp 50-64

Sue Reynolds, Lecturer: RMIT University, Melbourne
and PhD candidate, Charles Sturt University, Wagga
Wagga. Email: sue,revnolds armit.edu,au

$\mathrm{I}$ n November 1850, a bill to separate the District of Port Phillip from New South Wales was passed in England and on July 1, 1851, Port Phillip officially became the Colony of Victoria. Two wecks later, Charles La Trobe took an oath to serve as Lieutenant-Governor, and the day after his celebratory reception the discovery of gold in the colony was publicly announced by the Gold Discovery Committee.

The pride of the new government manifested itself in the rapid erection of nationalistic monuments, funded by its new wealth and intended to representits independence and support of learning and culture. The existing Supreme Court erected in 1843 to serve the Supreme Court of New South Wales had an additional and substantial courthouse constructed in 1853; the foundation stones of both the Melbourne Public Library and the University of Melbourne were laid by Lieutenant-Governor La Trobe on the same day in 1854; and grand Legislative Chambers were erected in just ten months during 1856. 
Even more aspirational than these general endeavours in the new Colony of Victoria was the foundation of significant libraries in the years immediately following Separation. Members of the Victorian legislature, the university's students and academics, legal professionals and the people of Melbourne were all promptly afforded access to library collections suitable for their particular purposes, even before permanent buildings in which to house the books were erected. Although the Colony of New South Wales established the first Australian libraries, Biskup points out that it was Victoria which 'led the country in the provision of library services for the public during most of the nineteenth century. ${ }^{2}$ In fact, one man led the way in Victoria: Redmond Barry, a twenty-six year old Anglo-Irish lawyer who had arrived in Melbourne in 1839, just four years after Port Phillip had been opened for settlement.

The gentlemen colonists appointed to govern the new Colony of Victoria, including Redmond Barry, had brought from Great Britain their own private book collections and a general understanding of libraries and their usefulness. The universities and Inns of Court they had attended as students prior to emigration had maintained libraries, as had the clubs to which they belonged. The new Houses of Parliament in London (built in 1848) included purpose-built library space and a Public Libraries Act was passed in England in 1850, but well in advance of this, Mechanics Institutes had been established for the education and 'rational amusement' of the general British public. There were also circulating libraries with holdings of less serious reading matter.

Ann Galbally, Barry's principal biographer; wrote that "Books and reading were the twin cornerstones of treasure and solace throughout Redmond Barry's life" and Barry's familiarity with libraries of various types was an unsurprising outcome of this devotion. Kirsop described Barry as 'the presiding genius of the Melbourne Public Library' and noted that he was familiar with 'different types of libraries ... [and] well aware of what such institutions could and should offer to the public'. The Royal Cork Institution, which incorporated a library, museum, and art gallery, was probably well known to Barry from youthful visits to that city, and both Cork and Dublin had subscription libraries of which Barry may well have been a member. He had a general and legal education acquired at Trinity College and King's Inns, Dublin and at Lincoln's Inn, London, all of which had important libraries. He recorded in his 'day books" many of the libraries, museums, and art galleries he visited prior to leaving Ireland in 1839. Redmond Barry not only brought a selection of his cherished books with him from Ireland to Australia (and noted his reading of them in his day books during the voyage), but also a personal passion for books and libraries an enthusiasm he desired to share. He gave frequent (and extremely lengthy) speeches laden with classical allusions gathered from his own reading, and during the 1840s he opened a library in his home to any Melbournian inclined to make use of it.

When Victoria separated from New South Wales, Redmond Barry a secure, priviledge, and active citizen involved with most of the cultural, social, and political developments in the colony, including the establishment of libraries. Peter Ryan, author of Barry's entry in the Austratian Dictionary of Biography, has written that "No society or association for public improvement, recreation 
or benefit could be launched without Mr Redmond Barry as founder, president, vice-president or patron. The Philosophical Institute, the Philharmonic Society, the Horticultural society, the Melbourne Hospital, the Melbourne Club, the Polo Club - in all these and many more he was prominent and no mere figurehead upon the committee." In the political sphere, Redmond Barry was appointed the first Solicitor-General of the Colony of Victoria but within a year, after entertaining a brief interest in standing for the Legislative Council, he became the second judge appointed to the Supreme Court of the Colony of Victoria. William a'Beckett was the chief justice, and Edward Eyre Williams the third judge but, fortuitously for Barry and the libraries of Victoria, a'Beckett became ill and went home to England for treatment, leaving Barry in the role of Acting Chief Justice for almost all of 1853 and 1854. This role, and the timing of it so soon after Separation, together with his other positions in the colony, gifted the energetic Barry to launch the public, parliament, university, and court libraries.

\section{LIBRARIES IN THE COLONY OF VICTORIA}

Barry, as the colony's first Solicitor-General, was a founding member of the Parliamentary Library Committee which established that library in November 1851, only a day after the very first session of the Legislative Council. Details regarding the nature of his apparently short-lived involvement with this endeavour are limited, ${ }^{8}$ but his authority as the most important judicial figure in the colony during 1853 and 1854, and his personal ambition, enabled him to become in rapid succession the foundation Chancellor of the University of Melbourne, after legislation establishing the University was introduced late in 1852 and passed early in 1853; the senior Trustee and Chairman of the Board of the Melbourne Public Library from July 1853; and the instigator and acting Chairman in a'Beckett's absence) of the Library Committee of the Supreme Court Library from its first meeting in April 1854. These were Barry's official positions with regard to the institutions and the libraries of each, but he had also been closely involved in the decisions to establish them before they formally existed. Gregory asserted that the expeditious founding of the Parliamentary Library indicates that "the decision to establish a library had clearly been made prior to the opening of the Legislative Council", and Galbally recorded that "ideas for a Public Library and a University had been floated as ways of commemorating Separation and the establishment of Victoria as a separate colony in July 1851. ${ }^{10}$ Reynolds has also provided evidence of library business being underway before the official establishment of the Library of the Supreme Court." In the last case, Barry's influence is evident in a report commissioned by Lieutenant-Governor Charles La Trobe in the early days of the new Colony of Victoria and the consequences of that report: ${ }^{12}$ Barry and his co-investigator, William Stawell, the colony's first Attorney-General, determined the need for a Supreme Court in the Colony resulting in an act to establish the Supreme Court, ${ }^{13}$ which in turn engendered the rules ${ }^{1+}$ allowing a library for the legal profession to be purchased. The rules were signed by William a'Beckett, Redmond Barry, and Edward Williams twelve months before the first meeting of the Library Committee, and they were known into the twentieth century as 'Barry's rules. 
Redmond Barry was then directly responsible for the establishment of the Library of the Supreme Court, the Melbourne Public Library, and University of Melbourne Library, with early involvement in the establishment of the Victorian Parliamentary Library. By Barry's own admission (or boast), these four libraries were deliberately positioned by him to be synergistic and complementary to each other, particularly with regard to their collections. As Chairman of the Trustees of the Melbourne Public Library Barry wrote a retrospective rationale for the relationship between the libraries in the Preface to the 1865 Supplemental Library Catalogue:

The Trustees were much influenced by the existence in Melbourne of three other libraries, the management of one or other of which they had the honor of being also connected. ${ }^{16}$ The [Parliamentary Library] at the outset contained chiefly works on constitutional lore and statistics. The [University Library] embraced classics ancient and modern - science, natural philosophy, natural history, general history and ... education. The [Supreme Court Library] is strictly professional ... confined to law, history, and general jurisprudence. $^{17}$

Barry expanded on this relationship later in the Preface, explaining that

during the early years of the foundation of these libraries, while the funds at the disposal of the Managers of each were meagre, the endeavour was to keep each library within the points of its special intention, namely, to supply the particular and technical information required by the statesman, the student and the practising lawyer [and] the Public Library supplementary to the others and thus avoid the needless multiplication of copies of the same book. ${ }^{18}$

With Redmond Barry as the connecting factor for each of the libraries, and in view of his sustained and prominent involvement with them (with the exception of the Parliamentary Library, with which he was directly connected for only its first six months), it is worthwhile to consider the 'librarianship' of each. Hubber noted that although "the management of a large reference library was not the exact science that it is today', Redmond Barry was 'not a mere amateur or dilettante ... [He] took it upon himself to lead by example, and so was quite prepared to immerse himself in the minutiae of the Library's operations". ${ }^{19}$ Did Barry, as the chief instigator, have a personal model of librarianship which he applied to all 'his' libraries, or did the staffing and management of each follow the general pattern of the times for each library type?

\section{NINETEENTH-CENTURY LIBRARIANSHIP}

Talbot asserts that until the end of the nineteenth century, libraries in Australia were small and had not reached the critical level of "incoming books, number of books on the shelves, number of readers, etc." ${ }^{20}$ which required a wide range 
of skills for management. They could, therefore, exist fairly satisfactorily with someone to 'keep things in order' as directed by a library committec. Francis Cass describes Australian colonial librarians as being in general either "fetcher[s] and carrier[s] "with a few special clerical tasks to perform" as instructed by the library committee, or as scholarly librarian $[\mathrm{s}] .{ }^{21}$ This division of 19 th-century Australian librarians into custodians or scholars reflects similar practice for the same time period in both the United States and England, was as implied by White when discussing Dewey's view of librarianship at the end of the nineteenth century as no longer "a side-job for first-rate minds or clerical work for factotums." ${ }^{22}$

In the United States, the "professionalization process" began in Philadelphia in 1876 at the first 'Convention of Librarians'. Hubber believes that in Australia "librarians in Melbourne were moving towards realizing a profession" by the $1880 \mathrm{~s}^{24}$, and goes on to make an argument for the existence of a "protoprofession' of librarianship in Victoria in the institute libraries of the 1880s. This had developed despite the absence of the accepted professional characteristics of "formal networking, [a] full panopoly of professional skills, a minimum standard of education, [and] transferable qualifications.

Barry's libraries were established thirty years before even a proto-profession can be argued to have existed, but Barry in fact contributed to the international development of the profession of librarianship by presenting two papers at the first international library conference, of which he was a vice-president, in London in 1877. Barry has even been credited as one of the founders of the British Library Association subsequent to the Conference ${ }^{20}$ there was no Australian professional association until 1894, fourteen years after Redmond Barry's death). Despite the non-existence of professional librarianship during Redmond Barry's lifetime he was indisputably responsible for the 'librarianship' of both the Public Library ${ }^{27}$ and the Supreme Court Library in Victoria ${ }^{2 !}$ The available evidence suggests that he was also, at the least, closely involved with the decisions made regarding the Parliamentary library at its first meetings, ${ }^{2 n}$ and the University library in its earliest stages.

\section{THE LIBRARY OF THE UNIVERSITY OF MELBOURNE}

Barry was the first Chancellor of the University of Melbourne, and at the end of 1853 he called for competitive design plans for the university buildings. $A$ 'Schedule' of accommodation was produced in connection with the competition. and it included a library," but there is very litule information about the operation of the library in the early days of the University. Ernest Scott recorded in his History of the University of Melbourne that the University Council, whose meetings were usually held in Barry's chambers at the Supreme Court. allocated a grant of L500 to establish a library for the first four professors appointed in $1854^{32}$, and the first library appears to have been housed in a room, known as the 'Robing Room, adjoining the Registrar's office. The University's archival records show that a Library Committee of the University Council was first convened in 1859. and a Library Committec of the Professorial Board in 1886. This second Library Committee kept a Minute Book from 1887 now in the University Archives and 
inserted loose between its covers is a 'List of Officers in Charge' (i.e. of the Library) from 1853. The first such officer was the Registrar of the University from 1853 to 1855, and in his book Scott suggests that "the first Registrar could easily be the Librarian also, because there was so little for him to do in either capacity." Students could borrow books from the Registrar, but could not use the room which stored them as a reading room. ${ }^{36}$ Listed after the first Registrar is "a clerk under the supervision of the Professorial Board" for 1855 and 1856. Chancellor Barry arranged for his associate, Charles Cumberland, to undertake this work, but the Board found this arrangement unsatisfactory, believing that the University needed someone in situ, rather than someone based at the Supreme Court, to receive and shelve the consignments of books arriving for the new University. There was a 'Registrar, Secretary and Librarian' from 1856 tol892, with various Assistant Librarians from 1865 to 1881. In 1865, the university registrar, Edward a'Beckett (son of Chief Justice William a'Beckett), moved the library away from his office and appointed the first sub or assistant librarian. ${ }^{37}$ At the same time, the Supreme Court Library created a similar position. By 1873 the 'permanent assistant librarian' at the University (assistant to the Registrar who was also the librarian) was expected to "fill the office beyond a mere perfunctory discharge of the duties actually prescribed", and the duties given were an amalgamation of those performed by the Supreme Court sub-librarian and by the judges' associates acting in turn as librarian. ${ }^{38}$ The assistant librarian at the University of Melbourne was expected to be on duty every day, to maintain and preserve the library collection, attend Library Committee meetings and act as its secretary, write lists of books ordered and received, file invoices and receipts, keep accounts and statistics of library use, prepare all books, and maintain an annual list of books in the collection. ${ }^{39}$ He was also to see that the 'orders and instructions' of the Committee were carried out and had no power in the library at all - except over the students of whom he should be able "to command ... respect"." In 1871 the University Registrar, Edward a'Beckett, reported to the President of the Professorial Board that the Library Committee, which had been in existence since 1860, had in fact not met since 1860 and did "not appear to have understood the nature of the functions they were expected to discharge"." It was Redmond Barry, the Chancellor of the University, who determined the duties of the assistant librarian two years later in a 'Draft Report of Library Committee' he prepared. ${ }^{12}$ According to the 'List of Officers in Charge', in the decade from 1882 until 1892 the library was cared for by either a library clerk or an assistant librarian, with the last assistant librarian being promoted to the position of librarian in 1892, relieving the registrar (Edward a'Beckett) of those duties.

\section{THE MELBOURNE PUBLIC LIBRARY}

At the Melbourne Public Library, five Trustees were appointed in 1853 to be responsible for the library's affairs. Redmond Barry was the senior Trustee and Chairman of the Board, which collectively had the power to make the rules and regulations for the library, and to select books for a collection aiming to represent "the best of everything," Charles Cumberland, Barry's associate, was 
employed at the Library from 1853 under Barry's supervision (concurrent with his employment at Supreme Court and subsequently, at the University). Barry not only directed the work of the library but on the day before the library's public opening 'toiled with his assistants until midnight to ensure that the books were unpacked, examined, and placed on the shelves in time for the ceremony " on February 11, 1856. The library's first official employee was a library porter, who had also been employed at the Supreme Court, but very shortly later, on May 5 , 1856, a librarian was appointed.

The first librarian was Augustus Tulk, who posessed the required qualifications of being "a scholar, a gentleman and a bookman." Despite Tulk being "like many librarians who followed him brought up to no particular calling," Edmund La Touche Armstrong, Chief Librarian 1896-1925, considered that "Victoria was fortunate in securing a man of such scholarship and versatility as its first Librarian." Tulk was paid $\mathcal{L} 252$ per annum to build up the collection according the principles established by Barry and the Trustees, and to provide a reference service to library users and to catalogue and classify the collection. ${ }^{18}$ These were activities well beyond the capabilities of a mere factotum, and far more extensive than those of the so-called librarians' at the Supreme Court and University who had no say whatsoever with regard to the library collections or their organisation. Ramsey claimed that until Tulk was appointed in 1856, Redmond Barry "filled the role of Librarian as well as Senior Trustee" and Tulk's obituary in The Age attributed the success of the library in "promoting its objects" to him "However, correspondence between Tulk and Barry in the library's letter books indicates that Barry was very much in charge of the library, and that he directed Tulk in his activities. Augustus Tulk was succeeded by Henry Sheffield in 1858 , but MeVilly's opinion is that Sheffield performed his duties as Redmond Barry dictated, and it was Barry rather than the nominal librarian who represented the Public Library at the Conference of Librarians held in London in 1877.

\section{THE LIBRARY OF THE PARLIAMENT OF VICTORIA}

Yet another library with which Redmond Barry was involved is the Victorian Parliamentary Library, founded on November 14, 1851. Barry was a member of the first Library Committee which almost immediately, appointed Charles Ridgway as an Assistant Clerk but he was no longer involved when the Committee promoted Ridgway to the position of Librarian in November 1856. Patrick Gregory wrote that the true work of the library was performed by the Committee, with Ridgway the "fetcher and carrier" who had "little to do with the development of the collection, a task that fell to the Committee and its London agents, and his work consisted more of checking the inventories against the contents of the ever-increasing number of crates, cataloguing "the unpacked books and doling them out to members." In 1863, Ridgway was replaced by James Smith, a journalist with the Melbourne newspapers The Age and the Argus and an editor of the Melbourne Punch. Smith's appointment, under the patronage of the Government Statistician William Archer, was controversial and clearly political. The appointment was announced in the Government Gazette which described Smith as having a "known ability, extensive knowledge of books, 
experience as a literary man, and general acquaintance with literature [which would] peculiarly qualify him for the discharge of the duties of Librarian." the time of Smith's appointment Redmond Barry's direct involvement with the Parliamentary Library had long ceased.

\section{THE LIBRARY OF THE SUPREME COURT OF VICTORIA}

American law libraries of the 19th century have been described as consisting "of a collection of judicial reports and little more", and it is claimed that "these libraries needed simple maintenance, not professional attention." of the Supreme of Victoria, from almost its earliest days, consisted of a far broader collection $^{53}$ than is reported for similar libraries in the United States. Redmond Barry and the Library Committee certainly paid it more attention than mere maintenance, particularly with regard to the collection and the library catalogues, but the first employee, a library porter, did play a simple curatorial role. From its first recorded meeting on April 5, $1854^{59}$, the Supreme Court Library was in the charge of a committee (as mandated by the Supreme Court Rules), which determined at a meeting on May 20, 1854 that (among other library rules) "No Book may be taken out of the Library until the library porter shall have entered the name of the Book, and of the gentleman to whom the same is given." ${ }^{60}$ The government agreed to provide the salary for a library porter throughout the $1850 \mathrm{~s}^{61}$, and Redmond Barry believed that the Supreme Court Library had no need for the position of librarian to be specially created since the judges' associates could easily act in that role, in "rotation as may be convenient". "Charles Cumberland, Justice Redmond Barry's associate, was the first to sign letters as 'Librarian',doing so on behalf of the Library Committee, and he had more experience in this role in view of his additional positions. At Barry's instigation, he served as secretary to the Trustees of the Melbourne Public Library and, for a short time, as a clerk with library responsibilities at the University of Melbourne. In 1865, John Schutt was employed by the Library Committee as a sub-librarian, with the associates still acting in turn as librarian, until 1870, when Schutt took over the role of librarian and secretary to the Library Committee. Shut remained librarian for a further 54 years under the direction of the Library Committee. ${ }^{63}$ Thus, in the early years, the daily activities of the Supreme Court Library were carried out by both a factotum and more educated judges' associates under the direction of a committee. This arrangement endured until the school master.John Schutt was employed, first as sub-librarian and then librarian with more extensive duties, but still as instructed by Redmond Barry and the Library Committee.

\section{COLONIAL LIBRARIANSHIP}

The four libraries established by Sir Redmond Barry, in close chronological proximity between 1851 and 1854, were the pre-eminent Victorian libraries of the colonial era. Rochester considered Australia colonial libraries according to type in order to establish a model of their staffing, and she determined that mechanics institute and free public libraries were commonly looked after by a "caretaker 
or custodian, appointed by the library committee to administer the institute'; university and parliamentary libraries "were supervised by administrative staff or learned amateurs"; and the public reference and lending libraries in each colonial capital were maintained by men with "good academic backgrounds." This is a refinement of Cass' classification of library staff into 'fetchers and carriers' or scholars. Cass' categorisation is based on the libraries of colonial New South Wales, whereas Rochester's model included the libraries of colonial Victoria.

From an analysis of the available sources, it seems that Barry, where he had the power to do so, did not impose a single model of librarianship in the libraries of the Colony of Victoria. Or did he impose a style of librarianship specific to each library type, such as was determined retrospectively by Rochester. Reynolds has asserted with regard to the Library of the Supreme Court of Victoria that Barry, as Chairman of the Library Committec, assumed responsibility for the operational 'librarianship' of that library despite the appellation of librarian being attached to others. This would seem to also be the case for each of the other libraries being considered, with the exception of the Parliamentary Library with which he had only a brief association. Redmond Barry's power and influence were such that he was able to direct the activities of each library, with the support of a committee and staff to enact his vision.

From 1853, the library of the University of Melbourne was supervised by 'administrative staff' and various assistant librarians until 1881, the year after Sir Redmond Barry's death. The position of university librarian did not exist until 1892. At the Melbourne Public Library, Charles Cumberland acted as a factotum alongside a library porter until Mr Tulk, considered to have a "good academic background", was appointed very soon after the library's opening in 1856. The situation at the Parliamentary Library was similar, but the deployment of a "learned amateur" to succeed the original curatorial librarian was not as rapid. Despite the title of librarian being assigned to Charles Ridgway in the early years of the library's existence, he merely performed simple factotum duties for the twelve years of his employment. The first employee of the Supreme Court Library was a library porter, fetching and carrying at the direction of the Library Committee. Concurrent with the employment of a porter, the educated judges' associates acted in turn as the 'librarian', and were thus 'scholarly', as was the assistant librarian appointed in 1865, John Schutt.

While the nature of the staff members appointed by the individual libraries varied, all of the libraries were administered by a committec, with Redmond Barry prominent in their activities and his influence on each of the developing libraries evident. The variant arrangements for the early years of the libraries" establishment were, however, in keeping with other colonial libraries of like kind, and generally conform to Maxine Rochester's model: the university library was under the immediate supervision of 'administrative staff', the parliamentary library by a 'learned amateur', and the public library by a man with a 'good academic background.' The Supreme Court Library, as a special library, is not a category included in Rochester's research, but the staff employed by its Library Committee clearly conformed with each of the two generalised nineteenthcentury librarian types suggested by Francis Cass: initially, there was a library 
porter who was 'a fetcher and carrier', with the judges' associates acting in the role of a more scholarly librarian. Then in the second decade of the library's existence, $\mathrm{Mr}$ Schutt was employed as an assistant librarian with "a few special clerical tasks to perform".

Neither Cass nor Rochester provide a reason for the variant types of staff in different types of libraries, and it is easy to assume that the variance was a result and accommodation of unique circumstances. However, if Barry's libraries are considered as a representative sample of colonial library types, then it is possible that the library staffing categorised by Cass and Rochester was an issue dependent on factors external to the libraries themselves, such as the status of the parent institution. Thus, in Victoria, the Public and Parliamentary libraries could afford, and perhaps even required, a scholarly librarian because they were highly regarded by the Parliament, generously funded, and able to swiftly enlarge their important collections. The university, although funded by the government, was for many years a small concern, and the library, neglected by its committee and even by Chancellor Barry who was busy with academic business, was therefore not in need of more than administrative attention. The Supreme Court Library was funded by the legal profession itself, with minor assistance from the government, which paid the salary of a porter for the first ten years. The Library Committee was autonomously responsible for the library, and conserved its funds by having the judges' associates act as 'librarians'.

The Trustees of the Melbourne Public Library included a 'brief history' of the Library in their 1870 report. ${ }^{67}$ Their historical summary also provided a comparison of various elements of the library's functioning with some of the other libraries in Melbourne. The report paid particular attention to the libraries which are the focus of this article and which formed a 'consortium' with the Public Library. The table below compares the 'book vote' for the libraries in the early years of their existence, indicating the disparity between the funds available for the book collections of the Public and Parliamentary libraries and those of the Supreme Court and University libraries:

Table 1: The book vote for each library 1853-1859

\begin{tabular}{|c|c|c|c|c|c|c|c|}
\hline & $\begin{array}{r}1853 \\
\mathcal{L}\end{array}$ & $\begin{array}{r}1854 \\
L\end{array}$ & $\begin{array}{r}1855 \\
L\end{array}$ & $\begin{array}{r}1856 \\
L\end{array}$ & $\begin{array}{r}1857 \\
\ell .\end{array}$ & $\begin{array}{r}1858 \\
6\end{array}$ & $\begin{array}{r}1859 \\
6\end{array}$ \\
\hline $\begin{array}{l}\text { Melbourne Public } \\
\text { Library }\end{array}$ & 3000 & 3000 & 3000 & 3000 & 5000 & 5000 & 5000 \\
\hline $\begin{array}{l}\text { Library of the } \\
\text { Parliament }\end{array}$ & 1200 & 2200 & 500 & 1000 & 3200 & 3000 & 2000 \\
\hline $\begin{array}{l}\text { Supreme Court } \\
\text { Library (self- } \\
\text { funded) }\end{array}$ & 400 & 525.15 .0 & 663.12 .6 & 143.0 .0 & 41.17 .4 & 208.5 .11 & 970.1 .3 \\
\hline $\begin{array}{l}\text { University of } \\
\text { Melbourne } \\
\text { expended) }\end{array}$ & -. & 3150 & 259 & 228.6 .10 & 43.18 .6 & 51.12 .0 & 59.12 .6 \\
\hline
\end{tabular}




\section{CONCLUSION}

In his study of New South Wales librarians, Cass summarises the general historical development of a library and its 'librarianship' as a continuum, with the early book stock administered by an honorary or part-time librarian. As the collection grew and there arose a need for greater control and rationalisation, a full-time librarian was appointed who eventually ended by solely managing the affairs of the library, (save for the occasional interference of some truculent member of the library committee which, though generally superfluous, continued to function ${ }^{63}$.

This is superficially true for the Victorian libraries under discussion, although the advances occurred at different stages for each library: a librarian was more speedily allowed to take charge at the Public and Parliamentary libraries than at the University and Supreme Court libraries, where it took decades for a librarian to be even appointed.

Although the libraries were closely linked by the ubiquity of Redmond Barry as a founding father (and certainly more than a truculent member of the library committee' until his death in 1880) and by his engagement of them in a consortium based on his intent that their collections complement rather than duplicate each other, ${ }^{69}$ they did not conform to a singular or unitary model of administration determined by Redmond Barry. This was despite his interest and involvement with the developing profession of librarianship. Rather, they exemplified the arrangements for each different 19th-century library type as defined by Maxine Rochester and Michael Cass, and in fact were doubtless an influence upon Rochester's typology. In line with Melvil Dewey's understanding of a 'real librarian' often being a trustee or committee member rather than "the one who bears that name"," it was Redmond Barry who was the force behind and within each of the libraries as they prospered. All of the libraries, whether a librarian was appointed earlier or later, were subject to the 'librarianship' of Redmond Barry, who presided over each institution's staff.

In 1884, just as the profession of librarianship solidified in Australia and the rest of the English speaking world, Clifford Holgate, visiting from England, reported on various libraries in 'Australia and Tasmania'. Holgate's survey of 'Libraries in the Antipodes" ${ }^{, 71}$, including all of Barry's libraries, was reported in a paper delivered at the annual meeting of the Library Association of the United Kingdom, in October 1884. He wrote in praise of these libraries and commented on Redmond Barry's involvement with them although Barry predeceased the survey by four years). The Melbourne Public Library exceeded 'all other Libraries in these colonies in size and value'; the Parliament Library was 'the most desirable for purposes of reference and study in the whole of Australia'; the Library of the Supreme Court had 'every reason to look forward to a useful, and even grand career'; and the Melbourne University Library was 'increasing year by year pretty equally in every department. ${ }^{72}$ Although no personal theory of librarianship on the part of Redmond Barry can be discerned, and the staffing of each library was typical of the period, if Holgate, and others, can be considered authoritative, then the librarianship of each can be considered successful and Barry's role and influence more substantial than that of the library employees. 


\section{REFERENCES}

1. Ray Wright A Blended House: The Legislative Council of Victoria 18511856 Melbourne Department of the Legislative Council, Parliament of Victoria 2001 ppl19, 132

2. Peter Biskup with the assistance of Doreen M Goodman Libraries in Australia Topics in Australasian Library and Information Studies 9 Wagga Wagga NSW Centre for Information Studies 1994 p81

3. Ann Galbally Redmond Barry: an Anglo-Irish Australian Carlton Vic Melbourne University Press 1995 p92

4. Wallace Kirsop 'Redmond Barry and Libraries' The La Trobe Journal Redmond Barry Number no. 73 p55

5. A series of daily records of one or two line descriptions sometimes using abbreviations. An incomplete series covering 1837-40 1842-47 1855-57 1860-62 1867-72 is held by the State Library of Victoria Barry Papers MS8380 602/1b

6. Peter Ryan Redmond Barry Great Australians London OUP 1972 p12

7. Redmond Barry was Acting Chief Justice from January 1853 to December 1854, except from October 27, 1853 to November 21, 1853, and also from July 8 to December 24, 1871 and from March 27, 1873 to January 12, 1875. Catalogue of the Library of the Supreme Court of Victoria 2nd ed Melbourne Stillwell and Knight Printers 1875

8. Patrick Gregory Speaking Volumes: the Victorian Parliamentary Library 18512001 [Melbourne] Victorian Parliamentary Library 2001 pl

9. Ibid

10. Galbally 93

11. Sue Reynolds 'A Nineteenth Century Library and its Librarian: Factotum, Bookman or Professional' The Australian Library Journal vol 56 nos 3\&4 November 2007 pp282-310

12. William F. Stawell and Redmond Barry An Official Report on the Administration of Justice at Separation' 29 September 1851 in J. M. Bennett and Alex C. Castles (eds) A Source Book of Australian Legal History: Source Materials from the Eighteenth to the Twentieth Centuries Sydney Law Book Company 1979 pp134-138

13. $15 \mathrm{Vict}$ No 10

14. 'Rules and Regulations' Victoria Government Gazette no. 2527 April 1853 p597

15. GBV 'Supreme Court Library' The Argus 19 April 1924 p6a

16. For example the first meeting of the Supreme Court Library Committee included amongst the attendees Public Library Trustees Redmond Barry and William Stawell

17. Preface to Supplemental Catalogue of 1865 in The Catalogue of the Public Library of Victoria Melbourne 1880 pxxix

18. Ibid. 
19. Brian Hubber 'Leading by Example: Barry in the Library' The La Trobe Journal Redmond Barry Number no. 73 p68

20. M R Talbot 'The Library Association of Australasia' in Elisabeth Morrison and Michael Talbot (eds) Books Libraries of Readers in Colonial Australia: Papers from the Forum on Australian Colonial Library History held at Monash University 1-2 June 1984 Clayton Vic Graduate School of Librarianship Monash University 1985 pl 18

21. Francis Michael Bernard Cass Librarians in New South Wales: A Study Occasional Papers in Librarianship 12 Adelaide Libraries Board of South Australia 1972 pp12-13

22. Carl M White A Historical Introduction to Library Education: Problems and Progress to 1951 Metuchen NJ Scarecrow Press 1976 p39

23. Dee Garrison Apostles of Culture the Public Librarian and American Society 1876-1920 New York Free Press c 1979 p7

24. Hubber 'The Proto-Profession of Librarianship the Richmond Public Library 1884' The Australian Library Journal vol 47 no 4 November 1998 p324

25. Ibid

26. Jean P Whyte, David J Jones Uniting a Profession: the Australian Institule of Librarians 1937-1949 Kingston ACT Australian Library and Information Association c2007 p8

27. See David McVilly A History of the State Library of Victoria 1853-1974 Master's Thesis Monash University 1975

28. See Reynolds A Nineteenth Century Library and its Librarian'

29. See Gregory $\mathrm{pl}$

30. See George Tibbits The Quadrangle: the First Building at the University of Melbourne Melbourne The University of Melbourne, History of the University Unit 2005 p 12

31. Ibid

32. Ernest Scott A History of the University of Melbourne Melbourne MUP in association with OUP 1936 p 137

33. Tibbits p51

34. 'List of Officers in Charge' Minute Book University of Melbourne Library Committee 1887-1925 103/122 volume I University of Melbourne Archives

35. Scott pl 20

36. Tibbits p51

37. Ian Morrison ' A Most Valuable Acquisition": Melbourne University Library and the bequest of George McArthur' The Australian Library Journal vol 56 nos $3 \& 4$ November 2007 p 268

38. Reynolds : N Nineteenth Century Library and its Librarian'

39. University of Melbourne Library 1854-1897 103/124 University of Melbourne Archives 
40. Ibid.

41. Edward a'Beckett, Registrar to President [of the Professorial Board, William Wilson] Library Committee's Report 18 March 1871 University of Melbourne Library 1854-1897 103/124

42. Ibid 'Draft Report of Library Committee Prepared by the Chancellor' February 71873

43. Edmund LaTouche Armstrong The Book of the Public Library Museums and National Gallery of Victoria 1856-1906 Melbourne Trustees Public Library Museums and National Gallery of Victoria 1906 pl1

44. Ibid., p4

45. McVilly p54

46. Ibid.

47. Armstrong p37

48. McVilly p54

49. Margery C. Ramsey 'Concept of a library: the Melbourne Public Library' in Morrison and Talbot p22

50. The Age 2 September $1873 \mathrm{p} 2$

51. Outward Letter Books: Melbourne Public Library VPRS 4366/P0000/2 Public Record Office of Victoria

52. McVilly p 59

53. Gregory p6 Ridgway was not officially gazetted as Librarian until 18 November 1856 though he was already referred to as Assistant Clerk and Librarian in the 1853 Budget

54. In the nineteenth century this was generally a straightforward alphabetical listing of books by title with some added information for each such as size publisher cost etc.

55. Gregory $\mathrm{p} 6$

56. Ibid., p18

57. Roy Balleste, Sonia Luna-Lamas, Lisa Smith-Butler (eds) Law Librarianship in the Twenty-First Century Lanham Maryland Scarecrow 2007 p3

58. Sue Reynolds 'Classics Room Treasures' in Law Institute Journal vol 79 no 7 July 2005 pp $28-30$

59. April 5 1854 Minute Book Library of the Supreme Court of Victoria

60. Ibid., May 201854

61. Reynolds 'A Nineteenth Century Library and its Librarian'

62. December 29, 1854, Minute Book, Library of the Supreme Court of Victoria

63. He died in office in 1919

64. Maxine Rochester Education for Librarianship in Austratia London Mansell 1997 p2

65. Reynolds 'A Nineteenth Century Library and its Librarian'

66. Although not included in Rochester, the Library of the Supreme Court 
of Victoria operated in the manner of proprietary libraries such as the Manchester Law Library established in 1820 as a specialist law library to serve any members of the legal profession in Manchester who purchased a subscription to it. Brenda Scragg The Manchester Law Library an Odyssey History of the Book Trade in the North PH84 Newcastle upon Tyne Robinson Library University of Newcastle upon Tyne 2002

67. The Trustces Report of the Trustees of the Public Library, Museums, and National Gallery of Victoria ... 1870-1871 Melbourne John Ferres, Printer [1871]

68. Cass p3

69. The Preface to Supplemental Catalogue of 1865 in The Catalogue of the Public Library of Victoria 1880 states that it was estimated that when the contents of the four Libraries were about 110000 volumes in the aggregate the number of copies of the works of the same authors repeated in the different libraries did not exceed 15000

70. Kenneth E Carpenter 'A library historian looks at librarianship' Daedalus vol 125 no 4 Fall 1996 p 77 and Reynolds : N Nineteenth Century Library and its Librarian' pp297-298

71. C. W Holgate An Account of the Chief Libraries of Austratia and Tasmania London C Whittingham 1886 Facsimile edition Occasional Papers in Librarianship 11 Adelaide Libraries Board of South Australia 1971

72. Ibid., ppl5-24 